\title{
Phenotypic plasticity to light of two congeneric trees from contrasting habitats: Brazilian Atlantic Forest versus cerrado (savanna)
}

\author{
F. de V. Barros ${ }^{1}$, M. F. Goulart ${ }^{2}$, S. B. Sá Telles ${ }^{1}$, M. B. Lovato ${ }^{3}$, F. Valladares ${ }^{4,5}$ \\ \& J. P. de Lemos-Filho ${ }^{1}$ \\ 1 Departamento de Botânica, Instituto de Ciências Biológicas, Universidade Federal de Minas Gerais, Belo Horizonte, Brazil \\ 2 Departamento de Ciências Biológicas, Universidade Federal dos Vales do Jequitinhonha e Mucuri, Diamantina, Brazil \\ 3 Departamento de Biologia Geral, Instituto de Ciências Biológicas, Universidade Federal de Minas Gerais, Belo Horizonte, Brazil \\ 4 Instituto de Recursos Naturales, Centro de Ciencias Medioambientales, CSIC, Madrid, Spain \\ 5 Departamento de Biologia y Geologia, Escuela Superior de Ciencias Experimentales y Tecnológicas, Universidad Rey Juan Carlos, Móstoles, Spain
}

\section{Keywords}

Adaptation; Atlantic Forest; cerrado; Dalbergia; ecophysiology; phenotypic plasticity

\section{Correspondence}

J. P. de Lemos-Filho, Departamento de Botânica, Instituto de Ciências Biológicas, Universidade Federal de Minas Gerais 31270, 901, Belo Horizonte, MG, Brazil.

E-mail: lemos@icb.ufmg.br

Editor

F. Loreto

Received: 18 November 2010; Accepted: 29 March 2011

doi:10.1111/j.1438-8677.2011.00474.x

\begin{abstract}
The Brazilian Atlantic Forest is a typically multi-layer tropical forest, while cerrado (savanna) is a patchy habitat with different physiognomy. Despite these differences, both habitats have high light heterogeneity. Functional traits of Dalbergia nigra and D. miscolobium from the Atlantic Forest and cerrado, respectively, were evaluated under shade (25\% of full sunlight) and full sunlight in a nursery experiment. We hypothesised that both species should benefit from high phenotypic plasticity in relation to light. Plasticity was estimated using the relative distance phenotypic index (RDPI). D. miscolobium had lower shoot growth under both light conditions, suggesting it has low competitive capacity in the forest environment, which could explain its limited ability to expand over areas of Atlantic Forest. The studied species exhibited photoprotection strategies under high light and improved light capture under low light. Stomatal conductance, $\mathrm{ETR}_{\max }$ (maximum electron transport rate), $\mathrm{PPFD}_{\text {sat }}$ (saturating photosynthetically active photon flux density), chlorophyll and carotenoid content had higher RDPI than stem morphological traits. Although both species showed considerable phenotypic plasticity, D. miscolobium had higher RDPI for eight of 11 evaluated traits. This high plasticity could be one of the factors that explain the occurrence of this species in a wide range of environmental conditions, from open grassland to dense woodlands, and it could also reflect its adaptation to high light. $D$. nigra also had considerable plasticity and good growth performance in both shade and full sunlight, but its absence in areas of cerrado suggests that factors other than light limit its occurrence in these habitats.
\end{abstract}

\section{INTRODUCTION}

Differences among species occupying contrasting environments can result from plant lineage divergence, from plastic responses to each environment or even from a pre-adaptation of the genotypes to a given selective factor or environmental condition (Reich et al. 2003). One way to distinguish how environmental factors are involved in the natural variation found in traits is to study phylogenetically related species that occupy contrasting environments. Several studies with phylogenetically related trees from forest and cerrado (Brazilian savanna), evaluating morphological and ecophysiological traits (e.g., Hoffmann \& Franco 2003; Hoffmann et al. 2005), suggested that they represent two distinct functional types, mainly related to differences in resource availability and fire frequency. The slight overlap in tree communities of cerrado and forest suggests that contrasting environmental conditions determines strong constraints on species distributions (Hoffmann \& Franco 2008). In fact, Hoffmann et al. (2004), in a study comparing seedling establishment success and subsequent survival between congeneric species from cerrado and forest, found that forest species had the lowest success in open environments and cerrado species had the lowest success in forest.

Structural differences in the cerrado and the Atlantic Forest impose different light conditions in the understorey. The Atlantic Forest is a multi-layer tropical forest (Lemos-Filho \& Mendonça-Filho 2000), whereas the cerrado is a patchy habitat composed of different physiognomies, varying from open grassland to dense woodland, generally associated with low fertility and well-drained soils (Oliveira-Filho \& Ratter 2002). It is widely recognised that light is a key limiting resource in forest ecosystems. Thus, it is expected that species originally from forest environments develop strategies to improve their competition for light, such as a vigorous stem growth (Valladares et al. 2002b). The same is not expected for species from the cerrado, which are not limited by light but by water and nutrient availability (Hoffmann \& Franco 2003). Cerrado 
environments are clearly more stressful and less productive than forests, so typical characteristics of stress-tolerance are expected in species from cerrado (Hoffmann \& Franco 2003).

Plants, as sessile organisms growing under heterogeneous light environments, exhibit a great capacity to adjust their morphology and physiology to the specific light condition of a site through acclimation or phenotypic plasticity (reviewed in Valladares \& Niinemets 2008). There are many concerns about the adaptive and evolutionary meaning of plasticity, but there is a consensus that phenotypic plasticity differs among species, traits and type of environmental factor considered (Valladares et al. 2006). In forest habitats, there is a great change in quality and quantity of light that reaches different strata of the canopy, which never closes completely, resulting in high levels of spatial and temporal light heterogeneity in the understorey (Pearcy 2007). Savannas and woodlands can also exhibit high light heterogeneity at ground level (e.g., Valladares \& Guzmán 2006; Lemos-Filho et al. 2010). There is also a wide variation in light availability among the different cerrado physiognomies (Prado et al. 2005). This heterogeneity of light at micro- and macro-spatial scales could lead to plant species that occur over different cerrado physiognomies having high phenotypic plasticity in relation to light.

In the present study, a nursery experiment was arranged to analyse phenotypic differentiation and phenotypic plasticity of functional traits in response to light availability among two congeneric tree species, Dalbergia nigra and Dalbergia miscolobium, from the Brazilian Atlantic Forest and cerrado (savanna), respectively. Considering the competitive pressure for light harvest in forest habitats, we expected D. nigra to have greater shoot growth than D. miscolobium and that this growth difference would be even greater in shade conditions. Physiological traits may show little or no genetic variation (e.g., Nicotra et al. 1997) and therefore it is expected that independently of origin, cerrado or forest, individuals exposed to high levels of irradiance will have similar chlorophyll fluorescence responses. Plants grown under full sunlight should also exhibit higher photosynthetic capacities than plants grown under low irradiance, as found in numerous comparative studies of sun- and shade-grown plants (Valladares \& Niinemets 2008). Taking the high light heterogeneity in the cerrado and Atlantic Forest environments into account, we hypothesised that both $D$. nigra and D. miscolobium should benefit from high phenotypic plasticity in relation to light availability. Analysis of morphological and physiological changes in response to light and quantitative evaluation of phenotypic plasticity could allow a better interpretation of the habitat preferences of these species, explaining the limited ability of cerrado species to expand over areas of Atlantic Forest and of forest species to expand over cerrado areas.

\section{MATERIAL AND METHODS}

\section{Species studied}

Dalbergia nigra (Vell.) Allemao ex Benth., commonly known as Brazilian rosewood, is a species of the Atlantic Forest that occurs in the southern parts of Bahia, in Espírito Santo, Minas Gerais, Rio de Janeiro, and on the north coast of São
Paulo (13-23 S; Carvalho 1994). It contains valuable timber that has been over-exploited, and therefore is nowadays considered vulnerable according to criteria of The World Conservation Union Red List of Threatened Species (IUCN 1994). Despite this vulnerability, high genetic diversity was found mainly in large protected reserves (Ribeiro et al. 2005, 2011). D. miscolobium Benth. is considered one of the most dominant species of the flora in the cerrado (Ratter et al. 2006), occurring from Piauí State in northeast Brazil, to Paraná in the south (7-24우 S; Gibbs \& Sassaki 1998). It can be found in all cerrado physiognomies, from open fields to dense woodland, known as 'cerradão' (Carvalho 1997). D. miscolobium is also known for its good quality wood and its use on degraded area rehabilitation programmes (Lorenzi 2002). D. nigra and D. miscolobium are included in the section Dalbergia of genus Dalbergia (Carvalho 1997), but a recent molecular phylogenetic study showed that $D$. nigra is more related to section Triptolemea (Ribeiro et al. 2007).

\section{Experimental design}

Seeds of both species were collected from eight individuals, from one population of D. nigra and one population of D. miscolobium. The seeds were maintained separately to evaluate the responses of the eight progeny from each species. Each progeny is constituted of seeds collected from the same open-pollinated tree, and thus they are at least halfsiblings. The population of D. nigra was from a permanently protected private area at Bom Jesus do Amparo $\left(19^{\circ} 45^{\prime} \mathrm{S}, 43^{\circ} 31^{\prime} \mathrm{W}\right)$, an Atlantic Forest core area. The population of D. miscolobium was from a cerrado area in a reserve at Zoo Botanic Foundation in Belo Horizonte $\left(19^{\circ} 56^{\prime} \mathrm{S}, 46^{\circ} 56^{\prime} \mathrm{W}\right)$. The seeds were pre-germinated and planted in 2.4-1 pots filled with organic substrate (3:1 enriched organic substrate:sand). These plants were submitted to a nursery experiment in Belo Horizonte $\left(19^{\circ} 56^{\prime} \mathrm{S}\right.$ $\left.46^{\circ} 56^{\prime} \mathrm{W}\right)$, where two workbenches $(1 \times 8 \mathrm{~m})$ were set up, each one representing a different light treatment (shade and full sunlight). We used an experimental design constituted by blocks, with three replicates within each light treatment. Each block contained six individuals of each tree progeny, with three individuals in each light treatment. Shade was provided using layers of shade cloth supported on wood frames, $1 \mathrm{~m}$ above the workbench surface and covering the sides. There was no water restriction for these plants. The plants were initially randomly disposed under each controlled condition and thereafter rearranged to prevent mutual shading. Measurements of photosynthetic photon flux density (PPFD) were taken at three points, on each workbench, on a clear day in May, using a quantum sensor (Li-Cor, Lincoln, NE, USA) at intervals of $30 \mathrm{~min}$. The shade treatment represented $25 \%$ of full sunlight (approximately $6.1 \mathrm{~mol} \cdot \mathrm{m}^{-2} \cdot \mathrm{day}^{-1}$ ).

\section{Morphological and physiological measurements}

Stem length and diameter were measured each month, from the second to the sixth month of growth. Using these values, the slenderness index was obtained as height/base diameter and the relative growth rate (RGR) was calculated as $\mathrm{RGR}=\left[\ln \left(\mathrm{x}_{2}\right)-\ln \left(\mathrm{x}_{1}\right)\right] / \mathrm{t}_{2}-\mathrm{t}_{1}$, where $\mathrm{x}_{1}$ and $\mathrm{x}_{2}$ are seedling 
length or stem diameter at times $t_{1}$ (second month-60 days) and $t_{2}$ (sixth month-180 days), respectively.

For physiological measurements, three individuals per progeny of each species were evaluated, resulting in 24 individuals of each species under each light treatment. Physiological measurements were made when the saplings were approximately 1 year old. We selected the newest fully expanded healthy leaf from each individual sampled. Stomatal conductance $\left(\mathrm{g}_{\mathrm{s}}\right)$ was determined in the morning (09:00 11:00 h) with a porometer AP4 (Delta-T Devices, Cambridge, UK). Chlorophyll $a$ fluorescence was measured with a portable chlorophyll fluorometer (MINI - PAM; Walz, Effeltrich, Germany). The maximum $\left(\mathrm{F}_{\mathrm{m}}\right)$ and basal $\left(\mathrm{F}_{0}\right)$ fluorescence yields were measured in dark-adapted (30 min) leaves at pre-dawn and midday, to determinate the potential quantum yield of photosystem II (PSII), calculated as: $\mathrm{F}_{\mathrm{v}} / \mathrm{F}_{\mathrm{m}}=\left(\mathrm{F}_{\mathrm{m}}-\mathrm{F}_{0}\right) / \mathrm{F}_{\mathrm{m}}$. Light saturation curves were obtained using the light curve programme of the instrument during $4 \mathrm{~min}$, with pulses saturating the irradiance applied every $30 \mathrm{~s}$ to obtain chlorophyll fluorescence parameters. To obtain the light saturation curves, all evaluated plants were previously adapted to the same diffuse light condition, over $2 \mathrm{~h}$. The effective quantum yield was calculated as: $\Delta \mathrm{F} / \mathrm{F}_{\mathrm{m}}^{\prime}=$ $\left(F_{\mathrm{m}}^{\prime}-\mathrm{F}\right) / \mathrm{F}_{\mathrm{m}}^{\prime}$, where $\mathrm{F}$ is steady-state fluorescence in the light and $\mathrm{F}_{\mathrm{m}}^{\prime}$ is maximum fluorescence in the light when saturating light is imposed. We also calculated the apparent photosynthetic electron transport rate (ETR), as 0.5 (PPFD) $\Delta \mathrm{F} / \mathrm{F}_{\mathrm{m}}^{\prime}$ 0.84. In this calculation, an equal partition of excitation energy between the photosystems was assumed, and 0.84 is the correction factor, assuming that only a fraction of the incident light is absorbed by the photosystems (Rascher et al. 2000). The relative excess PPFD was calculated as: $\left(\mathrm{F}_{\mathrm{v}} / \mathrm{F}_{\mathrm{m}}-\Delta \mathrm{F} / \mathrm{F}_{\mathrm{m}}^{\prime}\right) /\left(\mathrm{F}_{\mathrm{v}} / \mathrm{F}_{\mathrm{m}}\right)$, following Bilger et al. (1995). Data from light curves were used to determine maximum ETR values $\left(\mathrm{ETR}_{\max }\right)$ and saturating photosynthetic photon flux density $\left(\mathrm{PPFD}_{\text {sat }}\right)$ following Rascher et al. (2000). Leaf discs $\left(0.6 \mathrm{~cm}^{2}\right)$ from the same leaves used in fluorescence measurements were collected to quantify the pigment content. The pigments were extracted by grinding the discs in $5 \mathrm{ml} 80 \%$ acetone, followed by a second extraction of the pellet in $5 \mathrm{ml} 80 \%$ acetone. After centrifugation at $3000 \mathrm{~g}$ for 5 min, the two extracts were combined, and chlorophylls and total carotenoids were spectrophotometrically quantified using equations described in Lichtenthaler \& Wellburn (1983).

\section{Phenotypic plasticity estimates}

Phenotypic plasticity for the studied traits was estimated from the relative distance phenotypic index (RDPI), as described by Valladares et al. (2006). The relative distances (RD) was determined for all pairs of individuals of a given species or population grown under different light environments. The RD is calculated as $\mathrm{RD}_{\mathrm{ij} \rightarrow \mathrm{i}^{\prime} \mathrm{j}^{\prime}}=\mathrm{d}_{\mathrm{ij} \rightarrow \mathrm{i}^{\prime} \mathrm{j}^{\prime}} /\left(\mathrm{x}_{\mathrm{i}^{\prime} j^{\prime}}+\mathrm{x}_{\mathrm{ij}}\right)$, where $d_{i j \rightarrow i^{\prime} j^{\prime}}$ is the distance among trait values for all pairs of individuals, $j$ and $j^{\prime}$ are individuals belonging to the different light environments of $\mathrm{i}$ and $\mathrm{i}^{\prime}, \mathrm{x}_{\mathrm{ij}}$ is the trait value of individual $j$ under light treatment $i$, and $x_{i^{\prime} j^{\prime}}$ is the trait value of another individual $j^{\prime}$ in light treatment $i^{\prime}$. The RDPI ranges from 0 (no plasticity) to 1 (maximum plasticity) and is obtained as RDPI $=\Sigma\left(\mathrm{d}_{\mathrm{ij} \rightarrow \mathrm{i}^{\prime} \mathrm{j}^{\prime}} /\left(\mathrm{x}_{\mathrm{i}^{\prime} j^{\prime}}+\mathrm{x}_{\mathrm{ij}}\right)\right) / \mathrm{n}$, where $\mathrm{n}$ is the total number of RD. The RDPIs of morphological traits were to using only the data of the last evaluation (180 days). We used the mean value of each progeny for calculate RDPI. In each block, we obtained one mean, resulting in three mean values for each progeny under each treatment.

\section{Data analysis}

To evaluate the height, stem diameter, slenderness index and RGR, a factorial ANOvA with blocks was used. We considered the light treatments, species, blocks, growth days and interactions as the sources of variation. Some data were transformed into $\log (\mathrm{x}+1)$ to meet the assumptions of normality and variance homogeneity. The RGR values were transformed in arcsine $\sqrt{ }$. In the analysis of physiological traits, one individual of each progeny was used in each block. Some of these data were also transformed into $\log (\mathrm{x}+1)$ to meet the assumptions of normality and homogeneity. In case of non-normality, the Kruskal-Wallis test was used for comparing light treatments and species.

The RDPI values were used to compare plasticity of the species, and were arcsine $\sqrt{ }$ transformed to the assumptions of normality and homogeneity. Parametric values were compared using ANOVA, and a Kruskal-Wallis test was performed for non-parametric data. The statistical analysis and graphical display were performed with JMP (SAS Institute, USA) and OrIGIN 6.0 (OriginLab, MA, Cary, NC, USA) software packages, respectively. All differences were considered to be statistically significant if $\mathrm{P}<0.05$. Comparison of assembled traits, between the studied species, used paired t-tests or Wilcoxon matched pairs signed rank tests, for normal or non-parametric data, respectively, using the GRAPHPAD PRISM software (GraphPad Software, CA, USA).

\section{RESULTS}

\section{Morphological and physiological responses}

Dalbergia miscolobium exhibited slower shoot growth than D. nigra, with lower values of stem length $\left(\mathrm{F}_{1,1412}=1440.40\right.$, $\mathrm{P}<0.0001)$, stem diameter $\left(\mathrm{F}_{1,1412}=239.06, \quad \mathrm{P}<0.0001\right)$ and slenderness index $\left(\mathrm{F}_{1,1412}=1709.82, \quad \mathrm{P}<0.0001\right)$ (Fig. 1). A similar pattern was observed over the two light treatments for both species. Differences between light treatments were found in stem length $\left(\mathrm{F}_{1,1412}=65.10\right.$, $\mathrm{P}<0.0001)$ and stem diameter $\left(\mathrm{F}_{1,1412}=44.90, \mathrm{P}<0.0001\right)$, and in the slenderness index $\left(\mathrm{F}_{1,1412}=299.15, \mathrm{P}<0.0001\right)$. These traits had higher mean values in plants grown under shade conditions than in plants grown under full sunlight. Interactions between light and species were observed for stem diameter $\left(\mathrm{F}_{1,1412}=27.89, \mathrm{P}<0.0001\right)$ and slenderness index $\left(\mathrm{F}_{1,1412}=33.89, \mathrm{P}<0.0001\right)$. There was no significant block effect on stem diameter $\left(\mathrm{F}_{2,1412}=2.90, \mathrm{P}=0.055\right)$. A significant block effect was observed for stem length $\left(F_{2,1412}=\right.$ 15.13, $\mathrm{P}<0.0001)$ and slenderness index $\left(\mathrm{F}_{2,1412}=23.20\right.$, $\mathrm{P}<0.0001)$.

Dalbergia nigra had higher values of relative growth rate (RGR) for stem length than D. miscolobium $\left(\mathrm{F}_{1,282}=355.53\right.$, $\mathrm{P}<0.0001)$. This was also observed for stem diameter $\operatorname{RGR}\left(\mathrm{F}_{1,282}=440.55, \mathrm{P}<0.0001\right)$. The plants under shade also had higher RGR than the plants under full sunlight 

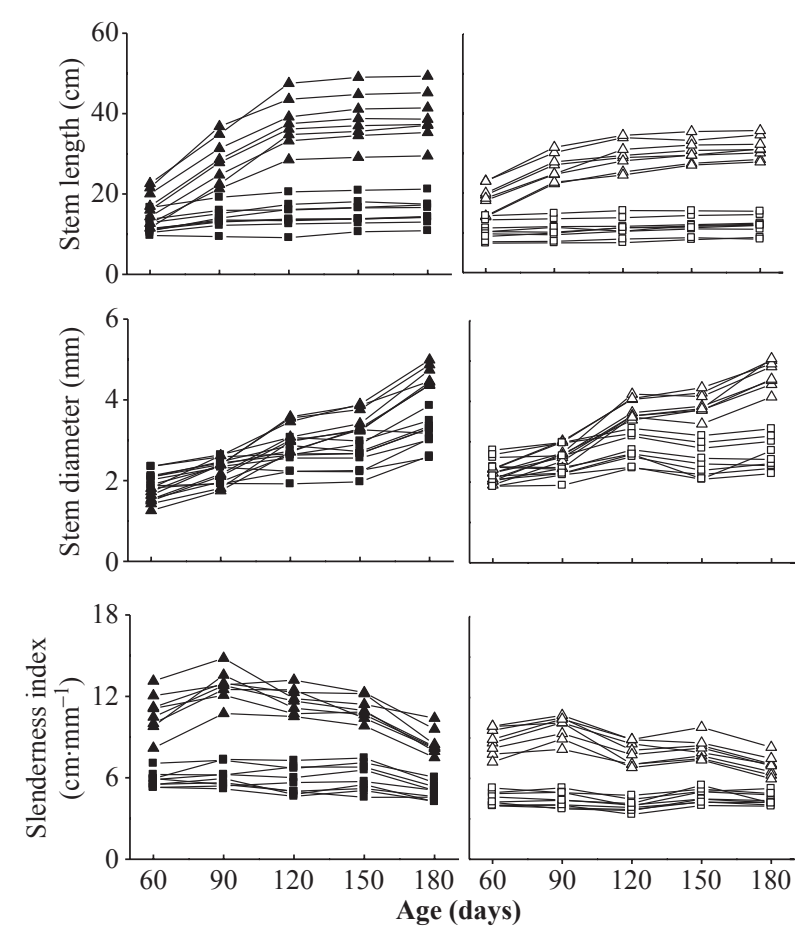

Fig. 1. Initial growth in Dalbergia nigra and D. miscolobium seedlings under full sun and shade conditions, represented by mean stem length $(\mathrm{cm})$, stem diameter $(\mathrm{mm})$ and slenderness index $\left(\mathrm{cm} \cdot \mathrm{mm}^{-1}\right)$ of $D$. nigra and D. miscolobium, measured over 180 days. Closed symbols represent shade and open symbols are full sunlight treatment. Triangle $(\Delta) D$. nigra, square $(\square)$ D. miscolobium. Each line represents mean obtained for all individuals of each progeny under each treatment.

conditions, for both measured characteristics: stem length $\left(\mathrm{F}_{1,282}=56.20, \mathrm{P}<0.0001\right)$ and stem diameter $\left(\mathrm{F}_{1,282}=\right.$ 50.97, $\mathrm{P}<0.0001)$. There was a significant interaction between species and light treatment stem length RGR $\left(\mathrm{F}_{1,282}=7.53, \mathrm{P}<0.0001\right)$. The values of $\mathrm{RGR}$ for shoot length of $D$. nigra and $D$. miscolobium in the shade was 0.21 and $0.06 \mathrm{~cm} \cdot \mathrm{month}^{-1}$, respectively, compared to 0.12 and $0.04 \mathrm{~cm} \cdot$ month $^{-1}$ under full sunlight. The RGR for stem diameter of D. nigra and D. miscolobium in the shade was 0.27 and $0.10 \mathrm{~mm} \cdot \mathrm{month}^{-1}$, respectively, compared to 0.19 and $0.05 \mathrm{~mm} \cdot \mathrm{month}^{-1}$ under full sunlight. In D. nigra, different growth patterns between shoot extension and stem diameter increases were observed. While stem diameter growth was similar to a stepped growth function, shoot extension reached a plateau after initial linear growth (Fig. 1). Thus, a significant decrease $\left(\mathrm{F}_{1,574}=16.65, \mathrm{P}<0.0001\right)$ in the slenderness index was observed when the values at 60 days were compared to those at 180 days.

The light saturation curves revealed contrasting photosynthetic performance of plants grown under different light conditions (Fig. 2), but a similar pattern was observed for both species. Plants grown under shade showed greater reduction of $\Delta \mathrm{F} / \mathrm{F}_{\mathrm{m}}^{\prime}$ with increasing light, when compared with plants from the sunlight treatment. As expected, sun-grown individuals had higher values of ETR than shade-grown individuals, with maximum ETR values of 62 and $38 \mu \mathrm{mol} \cdot \mathrm{m}^{-2} \cdot \mathrm{s}^{-1}$ for D. nigra and 62 and $34 \mu \mathrm{mol} \cdot \mathrm{m}^{-2} \cdot \mathrm{s}^{-1}$ for D. miscolobium
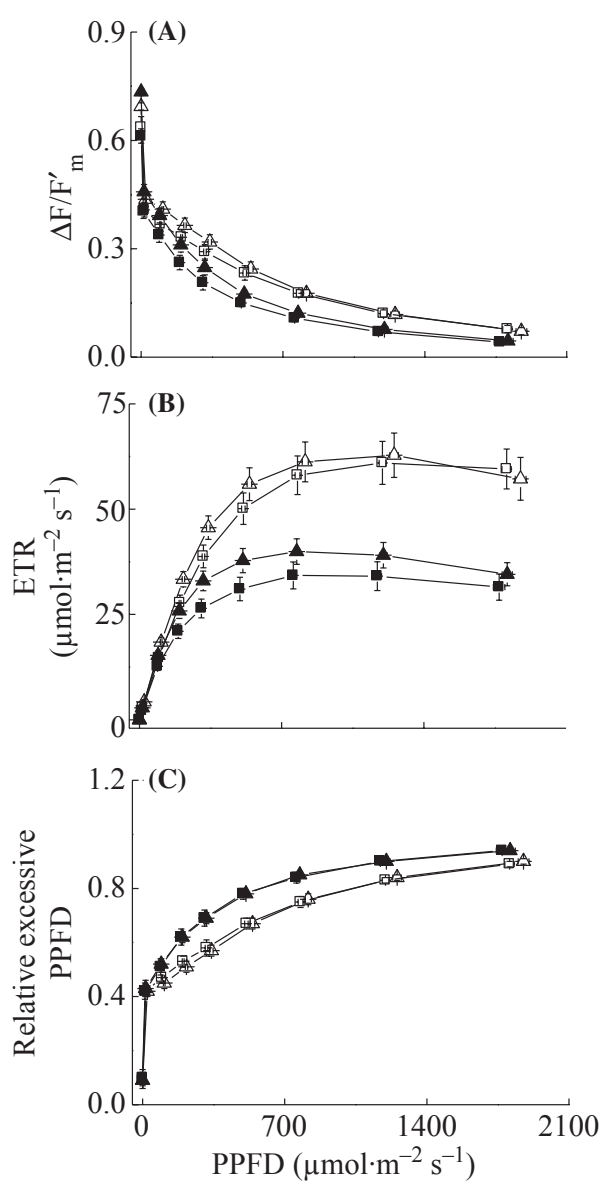

Fig. 2. Light saturation curves in seedling of Dalbergia nigra and D. miscolobium grown under full sun and shade conditions. Effective quantum yield of PSII $\left(\Delta \mathrm{F} / \mathrm{F}_{\mathrm{m}}^{\prime}\right)(\mathrm{A})$, apparent photosynthetic electron transport rate (ETR) (B), and relative excess photosynthetic photon flux density (PPFD) (C) are mean \pm SE. Triangle $(\Delta)$ D. nigra, square $(\square)$ D. miscolobium. The closed and open symbols represent, respectively, shade and sun treatments.

under full sunlight and shade, respectively. The values of PPFD at $90 \%$ of maximum ETR were 584 and $382 \mu \mathrm{mol} \cdot-$ $\mathrm{m}^{-2} \cdot \mathrm{s}^{-1}$ for D. nigra and 737 and $415 \mu \mathrm{mol} \cdot \mathrm{m}^{-2} \cdot \mathrm{s}^{-1}$ for D. miscolobium under full sunlight and shade, respectively (Fig. 2B). Even under low levels of PPFD, relative excess radiation (Fig. 2C) was approximately $40 \%$ in D. nigra and D. miscolobium for plants in both light treatments. However, shade-grown individuals had a greater increase in relative excess PPFD than sun-grown individuals when the high light intensity was imposed.

Analysis of physiological traits showed significant differences between light treatments, except for $\mathrm{F}_{\mathrm{v}} / \mathrm{F}_{\mathrm{m}}$ at pre-dawn and midday. In general, saplings grown under full sunlight had higher ETR $_{\max }\left(\mathrm{F}_{1,44}=42.21, \quad \mathrm{P}<0.0001\right), \quad \mathrm{PPFD}_{\text {sat }}$ $\left(\mathrm{F}_{1,44}=46.74, \quad \mathrm{P}<0.0001\right) \quad$ and chlorophyll $a / b$ $\left(\mathrm{F}_{1,44}=56.82, \mathrm{P}<0.0001\right)$, but lower chlorophyll content $\left(\mathrm{F}_{1,44}=35.13, \mathrm{P}<0.0001\right) \quad$ (Fig. 3) than saplings grown under shade conditions. Although there was an apparent reduction in $\mathrm{F}_{\mathrm{v}} / \mathrm{F}_{\mathrm{m}}$ measured at pre-dawn compared to that at midday, this decrease was not significant (Fig. 3B and C). D. nigra and D. miscolobium showed a significant difference 

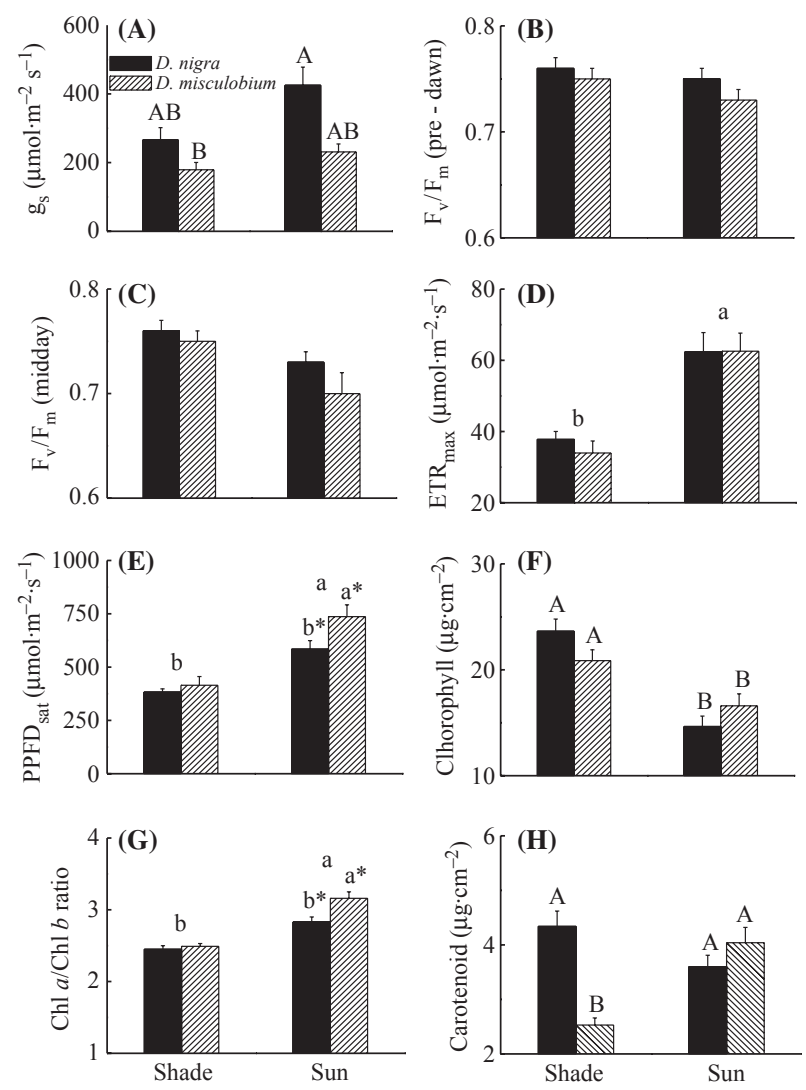

Fig. 3. Physiological responses to light of seedlings of Dalbergia nigra (black bars) and D. miscolobium (dashed bars). The graphs represent means \pm SE values of $(A)$ stomatal conductance $\left(g_{s}\right)$, (B) potential quantum yield of $\mathrm{PSII}\left(\mathrm{F}_{\mathrm{v}} / \mathrm{F}_{\mathrm{m}}\right)$ at pre-dawn, (C) $\mathrm{F}_{\mathrm{v}} / \mathrm{F}_{\mathrm{m}}$ at midday, (D) maximum apparent photosynthetic transport rate $\left(E T R_{\max }\right),(E)$ saturating photosynthetic photon flux density (PPFDsat), (F) total chlorophyll, (G) chlorophyll $a / b$ and $(\mathrm{H})$ total carotenoids. Capital letters compare each combination of light and species; lowercase letters compare light treatments and those followed by an asterisk ${ }^{*}$ ) compare the species, considering $\mathrm{P}<0.05$ as statistically significant. There was no difference in $F_{v} / F_{m}$ pre-dawn and midday values.

in $\mathrm{g}_{\mathrm{s}} \quad\left(\mathrm{F}_{1,44}=5.33, \quad \mathrm{P}<0.05\right), \quad \operatorname{PPFD}_{\text {sat }} \quad\left(\mathrm{F}_{1,44}=7.31\right.$, $\mathrm{P}<0.01)$, total carotenoid content $\left(\mathrm{F}_{1,44}=7.08, \mathrm{P}<0.01\right)$ and chlorophyll $a / b \quad\left(\mathrm{~F}_{1,44}=5.46, \mathrm{P}<0.05\right)$. The $\mathrm{g}_{\mathrm{s}}$ was higher in D. nigra than in D. miscolobium, while PPFD $_{\text {sat }}$ and chlorophyll $a / b$ were higher in $D$. miscolobium. Interactions between light and species were observed for carotenoid content $\left(\mathrm{F}_{1,44}=21.22, \quad \mathrm{P}<0.0001\right)$ and total chlorophyll $\left(\mathrm{F}_{1,44}=4.27, \mathrm{P}<0.05\right)$. D. nigra carotenoid content was statistically similar for both treatments, but the quantity of carotenoids was significantly higher in saplings of D. miscolobium exposed to full sunlight (Fig. $3 \mathrm{H}$ ).

\section{Phenotypic plasticity}

Plasticity levels (Table 1) were generally higher for physiological than for morphological traits. The RDPI for shoot length, stem diameter and slenderness index was below 0.2. RGR plasticity varied from 0.2 to 0.35 . The means for morphological trait plasticity were 0.17 for D. nigra and 0.22 for
D. miscolobium. In contrast, most of the physiological traits were higher than 0.2 (Table 1 ). The minimum was 0.08 for chlorophyll $a / b$ and the maximum was 0.36 for stomatal conductance, both in $D$. nigra. The mean for D. nigra was 0.23 and for D. miscolobium it was 0.25 . Almost all of the traits were significantly more plastic in D. miscolobium, except the slenderness index, stomatal conductance and total chlorophyll, which were higher in D. nigra.

The phenotypic plasticity values of fluorescence traits $\left(\mathrm{ETR}_{\max }\right.$ and $\left.\mathrm{PPFD}_{\text {sat }}\right)$ were significantly higher for D. miscolobium than D. nigra. However, significant differences were not detected for $\mathrm{ETR}_{\max }$ between the studied species under the same light conditions (Fig. 3D). This apparent contradiction could be explained by the way in which RDPI is calculated: it includes multiple comparisons of the same genotype, resulting in a more sensitive index to detect differences between genotype/species. Despite these differences between D. nigra and D. miscolobium in some traits, the species did not differ in relation to mean of the physiological trait RDPI (Wilcoxon test, $\mathrm{P}=0.687$ ): 0.23 for $D$. nigra and 0.25 for D. miscolobium (Table 1). Considering growth characteristics, D. miscolobium had higher RDPIs for stem length growth $\left(\mathrm{F}_{1,1258}=9.06, \quad \mathrm{P}<0.01\right)$, stem diameter $\left(\mathrm{F}_{1,1258}=47.48\right.$, $\mathrm{P}<0.0001), \mathrm{RGR}$ of height $\left(\mathrm{F}_{1,1258}=27.58, \mathrm{P}<0.0001\right)$ and RGR of stem diameter $\left(\mathrm{F}_{1,1258}=171.98, \mathrm{P}<0.0001\right)$, but the RDPI for slenderness index was higher in $D$. nigra $\left(\mathrm{F}_{1,1258}=11.66, \mathrm{P}<0.001\right)$. The analysis of growth trait RDPI means did not give significant differences between the two species (Wilcoxon test, $\mathrm{P}=0.125$ ), with mean values of 0.17 and 0.22 for D. nigra and D. miscolobium, respectively (Table 1).

\section{DISCUSSION}

Dalbergia nigra and D. miscolobium grown in a nursery experiment exhibited differences in morphological and physiological traits, suggesting genetic differences in ecologically relevant features. Some of these different characteristics could represent adaptations to their natural habitats. The vigorous shoot growth observed in the shade treatment, especially for the forest species, D. nigra, suggests a shade-avoidance syndrome, characterised by accelerated shoot growth (Valladares \& Niinemets 2007). This strategy is important for maximising light harvesting (Alvarenga et al. 2003; Hoffmann \& Franco 2003). This mechanism has a central role in forest areas, where light is a limiting resource, allowing species to compete spatially with other species that exhibit rapid growth (Groninger et al. 1996). In contrast to D. nigra, reduced shoot growth of D. miscolobium would not allow it to compete well for light, which may explain its limited capacity to expand over forest habitats.

Even under shade conditions, D. miscolobium seedlings were healthy at the end of the experiment. Lower RGR of shoots in D. miscolobium could be related not only to absence of shade tolerance, but also to biomass investment into roots. It is known that savanna species allocate more biomass to roots than forest species (Hoffmann \& Franco 2003). These differences in stem and root growth between plants from cerrado and from Atlantic Forest can limit occurrence of the species outside their current ecological niche. D. nigra had good development under both light con- 
Table 1. Plasticity index (RDPI) in relation to light and SE (standard error) of morphological and physiological traits of Dalbergia nigra and D. miscolobium.

\begin{tabular}{|c|c|c|c|c|}
\hline & \multicolumn{2}{|c|}{ D. nigra } & \multicolumn{2}{|c|}{ D. miscolobium } \\
\hline & mean & SE & mean & SE \\
\hline \multicolumn{5}{|l|}{ morphological traits } \\
\hline height & $0.15^{\mathrm{b}}$ & 0.006 & $0.17^{\mathrm{a}}$ & 0.006 \\
\hline stem diameter & $0.10^{b}$ & 0.004 & $0.13^{\mathrm{a}}$ & 0.005 \\
\hline slenderness index & $0.12^{\mathrm{a}}$ & 0.005 & $0.10^{\mathrm{b}}$ & 0.004 \\
\hline RGR height & $0.28^{\mathrm{b}}$ & 0.012 & $0.35^{\mathrm{a}}$ & 0.013 \\
\hline RGR stem diameter & $0.20^{\mathrm{b}}$ & 0.008 & $0.34^{a}$ & 0.013 \\
\hline mean & $0.17^{a}$ & & $0.22^{\mathrm{a}}$ & \\
\hline \multicolumn{5}{|l|}{ physiological traits } \\
\hline stomatal conductance & $0.36^{\mathrm{a}}$ & 0.01 & $0.25^{\mathrm{b}}$ & 0.01 \\
\hline $\mathrm{ETR}_{\max }$ & $0.28^{\mathrm{b}}$ & 0.01 & $0.35^{\mathrm{a}}$ & 0.01 \\
\hline $\mathrm{PPFD}_{\text {sat }}$ & $0.22^{\mathrm{b}}$ & 0.01 & $0.34^{\mathrm{a}}$ & 0.01 \\
\hline chlorophylls & $0.26^{a}$ & 0.01 & $0.19^{b}$ & 0.01 \\
\hline chlorophyll $a / b$ ratio & $0.08^{b}$ & 0.00 & $0.12^{\mathrm{a}}$ & 0.00 \\
\hline carotenoids & $0.18^{\mathrm{b}}$ & 0.01 & $0.23^{\mathrm{a}}$ & 0.01 \\
\hline mean & $0.23^{a}$ & & $0.25^{a}$ & \\
\hline
\end{tabular}

$\mathrm{RGR}=$ relative growth rate; $\mathrm{ETR}_{\max }=$ maximum apparent photosynthetic transport rate; $\mathrm{PPFD}_{\text {sat }}=$ saturating photosynthetically active photon flux density.

Different letters correspond to significant differences $(P<0.05)$ between species. ANOVA and Kruskal-Wallis test were used to compare individual traits, and Wilcoxon matched paired signed test to compare means of the evaluated traits.

ditions, which indicates that other factors frequently observed in neotropical savanna, such as high aluminium content, low nutrient availability, seasonal drought and frequent fires, could be involved in limiting its expansion to areas of cerrado. According to Hoffmann et al. (2004), restrictions in water availability and microclimate may be related to the low establishment and survival of D. nigra in cerrado areas, but fire could be a much more constraining factor explaining the low success of forest species in cerrado. In fact, fire and herbivory were cited as important factors that limit species occurrence in savanna (Midgley et al. 2010). According to Hoffmann et al. (2009), in forest-savanna boundaries the high burn frequency prevents forest species from invading savanna areas. In addition, the requirement for well-ventilated and less humid soils could limit D. miscolobium in forest areas. In fact, flooding intolerance has already been described for some species from cerrado (Joly \& Crawford 1982).

It is widely accepted that decreased $\mathrm{F}_{\mathrm{v}} / \mathrm{F}_{\mathrm{m}}$ values are a diagnostic indicator of photoinhibition (Maxwell \& Johnson 2000). In the present study, $\mathrm{F}_{\mathrm{v}} / \mathrm{F}_{\mathrm{m}}$ values at pre-dawn and midday did not differ statistically between species and light conditions, which suggest that sun-grown plants of D. nigra and D. miscolobium apparently did not suffer significant photoinhibition stress. The maximum quantum yield is considered a conservative trait that usually exhibits little variation among $\mathrm{C}_{3}$ species, unless under stressful conditions (Björkman \& Deming-Adams 1987). The light-response curves showed that sun-grown plants of both studied species had a higher maximum apparent electron transport rate $\left(\mathrm{ETR}_{\max }\right)$ when compared to shade-grown plants, and this could suggest high photochemical capacity of the sun-adapted plants.

Higher chlorophyll content in plants of both species grown in shade led to increased light harvesting efficiency at the leaf level. Lower chlorophyll $a / b$ in plants grown in shade compared to full sun is a result of an increase in chlorophyll $b$, which is a method to enhance light capture in the understorey (Lüttge 1997). The higher chlorophyll $a / b$ in sun-grown leaves is commonly interpreted as an indication of a higher ratio of core complexes to light-harvesting complexes, shifting the emphasis from light harvesting towards high rates of photochemistry (Demmig-Adams 1998). Thus, in sunny conditions, high chlorophyll $a / b$ would have resulted in low light absorbance by PSII, which reduces high radiation stress, as pointed out by Krause et al. (2001). The higher carotenoid content found in D. miscolobium under the full sunlight when compared with plants in shade is compatible with its role in photoprotection of the photosynthetic apparatus (Demmig-Adams \& Adams 1996). Another important role of these pigments is to maximise light capture in shade environments (Valladares et al. 2003; Sánchez-Gómez et al. 2006), which could explain the higher carotenoid content in individuals of D. nigra grown in shade. This high level of carotenoids could also be an advantage in protecting PSII against high irradiance, when sun penetrates through the canopy. The results show that D. nigra and D. miscolobium did not differ in chlorophyll fluorescence parameters, but showed differences in carotenoids when growing in shade, suggesting the ecological importance of these accessory pigments in modulating light absorption and dissipation.

Chlorophyll fluorescence parameters, stomatal conductance and chlorophyll and carotenoid content had higher values of plasticity (RDPI) than stem morphological traits. This agrees with the general pattern observed in high light-adapted species in contrast to species capable of coping with deep shade (Valladares et al. 2005; Valladares \& Niinemets 2008). D. miscolobium is found from open fields to dense woodland of cerrado, and D. nigra is an emergent tree of Atlantic Forest, although saplings can be found in more shaded understorey sites (personal observation); however, the plasticity pattern of D. nigra and D. miscolobium suggests sun-tolerance for both species. D. nigra and D. miscolobium exhibited significant differences in plastic phenotypic responses to light for most of the evaluated traits, although these differences varied among them. Phenotypic plasticity is advantageous in heterogeneous environments, while phenotypic stability seems to be adaptive under multiple co-occurring stresses and in adverse environmental conditions (Valladares et al. 2007). The greater plasticity to light of D. miscolobium for eight out of the 11 variables could be related to characteristics of its highly heterogeneous habitat. This high plasticity could be one factor that explains the occurrence of this species in a wide range of environmental conditions, from open fields to dense woodland (cerradão). High plasticity mainly in physiological traits seems to be linked to increased capacity to survive and grow in areas of potentially intense radiation (Valladares et al. 2002a) and thus the greater phenotypic plasticity of the cerrado species could also reflect adaptation to higher light levels. In D. miscolobium this high plasticity in relation to light would allow seedlings to compete for light with the thick grass layer of the cerrado during plant establishment, or even 
with woody species. Although D. nigra had lower plasticity than D. miscolobium, it still sufficient phenotypic plasticity that would allow it to deal with different light conditions. The considerable phenotypic plasticity observed in D. nigra can be an adaptive response to light heterogeneity in the Atlantic Forest.

Despite its higher phenotypic plasticity, D. miscolobium was a poor competitor for light, which could limit its expansion to areas of the Atlantic Forest, a highly competitive environment. The boundaries of both the Atlantic Forest and cerrado are temporarily and spatially dynamic in response to climatic changes. The expansion and retraction of neotropical savanna and forests during the late Pleistocene and Holocene have been well documented (Behling 1998, 2002). In a recent study, Silva et al. (2008) suggested that expansion of forest area bordering the central Brazilian savanna during inter-glacial periods could be related to indirect effects of a cold and moist climate. They presumed that an increase of water availability could have caused decreasing fire frequency in areas bordering the forests. This could explain the expansion of forest species into cerrado areas, but cannot explain the retraction of savanna trees from the new forest environment. In spite of the relatively high plasticity in many studied traits, the low competition capacity of cerrado species in relation to light would result in their suppression when the forest environment is expanding. The forest species, D. nigra, despite its good growth performance in both shade and full sun, does not occur in areas of cerrado, suggesting that factors other than light are involved in its limited occurrence in forest habitats.

\section{ACKNOWLEDGEMENTS}

F.V.B. received an MSc fellowship from the Coordenação de Aperfeiçoamento de Pessoal de Nível Superior (CAPES). M.B.L and J.P.L.F. received a research fellowship from the Conselho Nacional de Desenvolvimento Científico e Tecnológico (CNPq). Financial support was provided by the Fundação de Amparo à Pesquisa do Estado de Minas Gerais (FAPEMIG). We are thankful to Marcos and Ana Clara for assistance in the field measurements and to everybody who has contributed to this experiment.

\section{REFERENCES}

Alvarenga A.A., Castro E.M., Junior E.C.L., Magalhães M.M. (2003) Effects of different light levels on the initial growth and photosynthesis of Croton urucurana Baill. in southeastern Brazil. Revista Árvore, 27, 53-57.

Behling H. (1998) Late Quaternary vegetational and climatic changes in Brazil. Review of Paleobotany and Palynology, 99, 143-156.

Behling H. (2002) Carbon storage increases by major forest ecosystems in tropical South America since the Last Glacial Maximum and the early Holocene. Global Planetary Change, 33, 107-116.

Bilger W., Schreiber U., Bock M. (1995) Determination of the quantum efficiency of photosystem II and non-photochemical quenching of chlorophyll fluorescence in the field. Oecologia, 102, 425-432.

Björkman O., Deming-Adams B. (1987) Photon yield of $\mathrm{O}_{2}$ evolution and chlorophyll fluorescence at $77 \mathrm{k}$ among vascular plants of diverse origin. Planta, 170, 489-504.

Carvalho P.E.R. (1994) Espécies florestais Brasileiras Recomendações Silviculturais, Potencialidades e Uso da madeira. Embrapa, Brasília, Brazil.

Carvalho A.M. (1997) A synopsis of the genus Dalbergia (Fabaceae: Dalbergieae) in Brazil. Brittonia, 49, 87-109.

Demmig-Adams B. (1998) Survey of thermal energy dissipation and pigment composition in sun and shade leaves. Plant Cell Physiology, 39, 474-482.

Demmig-Adams B., Adams W.W. (1996) The role of xanthophyll cycle carotenoids in the protection of photosynthesis. Trends in Plant Science, 1, 21-26.

Gibbs P., Sassaki R. (1998) Reproductive biology of Dalbergia miscolobium Benth. (Leguminosae - Papilionoideae) in SE Brazil: the effects of pistillate sorting on fruit-set. Annals of Botany, 81, 735-740.

Groninger J.W., Seiler J.R., Peterson J.A., Kreh R.E. (1996) Growth and photosynthetic responses of four Virginia Piedmont tree species to shade. Tree Physiology, 16, 773-778.

Hoffmann W.A., Franco A.C. (2003) Comparative growth analysis of tropical forest and savanna woody plants using phylogenetically independent contrasts. Journal of Ecology, 91, 475-484.

Hoffmann W.A., Franco A.C. (2008) The importance of evolutionary history in studies of plant physiological ecology: examples from cerrados and forests of central Brazil. Brazilian Journal of Plant Physiology, 20, 247-256.

Hoffmann W.A., Orthen B., Franco A.C. (2004) Constraints to seedling success of savanna and forest trees across a savanna-forest boundary. Oecologia, $140,252-260$.

Hoffmann W.A., Franco A.C., Moreira M.Z., Haridasan M. (2005) Specific leaf area explains differences in leaf traits between congeneric savanna and forest trees. Functional Ecology, 19, 932-940.

Hoffmann W.A., Adasme R.A., Haridasan M., Carvalho M., Geiger E.L., Pereira M.A.B., Gotsch S.G., Franco A.C. (2009) Tree topkill, not mortality, governs the dynamics of alternate satble states at savanna-forest boundaries under frequent fire in central Brazil. Ecology, 90, 1326-1337.

IUCN. (1994) Red list categories. IUCN Species Survival Commission, Gland, Switzerland.

Joly C.A., Crawford R.M.M. (1982) Variation in tolerance and metabolic responses to flooding in some tropical trees. Journal of Experimental Botany, 33, 799-809.

Krause G.H., Koroleva O.Y., Dalling J.W., Winter K. (2001) Acclimation of tropical tree seedlings to excessive light in simulated tree-fall gaps. Plant, Cell and Environment, 24, 1345-1352.

Lemos-Filho J.P., Mendonça-Filho C.V. (2000) Seasonal changes in the water status of three woody legumes from the Atlantic Forest, Caratinga, Brazil. Journal of Tropical Ecology, 16, 21-32.

Lemos-Filho J.P., Barros C.F.A., Dantas G.P.M., Dias L.G., Mendes R.S. (2010) Spatial and temporal variability of canopy cover and understory light in a Cerrado of Southern Brazil. Brazilian Journal of Biology, 70, 19-24.

Lichtenthaler H.K., Wellburn A.R. (1983) Determination of total carotenoids and chlorophylls $\mathrm{a}$ and $\mathrm{b}$ of leaf extracts in different solvents. Biochemical Society Transactions, 11, 591-592.
Lorenzi H. (2002) Árvores brasileiras: manual de identificação e cultivo de plantas arbóreas do Brasil. Instituto Plantarum, Nova Odessa, Brazil.

Lüttge U. (1997) Physiological ecology of tropical plants. Springer, Berlin, Germany.

Maxwell K., Johnson G.N. (2000) Chlorophyll fluorescence - a practical guide. Journal of Experimental Botany, 51, 659-668.

Midgley J.J., Lawes M.J., Chamaillé-Jammes S. (2010) Savanna woody plant dynamics: the role of fire and herbivory, separately and synergistically. Australian Journal of Botany, 58, 1-11.

Nicotra A.B., Chazdon R.L., Schlichting C.D. (1997) Patterns of genotypic variation and phenotypic plasticity of light response in two tropical Piper (Piperaceae) species. American Journal of Botany, 84, 1542-1552.

Oliveira-Filho A.T., Ratter J.A. (2002) Vegetation physiognomies and woody flora of the cerrado biome. In: Oliveira P.S., Marquis R.J. (Eds), The cerrados of Brazil. Columbia University Press, New York, NY, USA, pp. 91-120.

Pearcy R.W. (2007) Responses of plants to heterogeneous light environments. In: Pugnaire F., Valladares F. (Eds), Functional plant ecology. CRC Press, Boca Raton, FL, USA, pp. 213-258.

Prado C.H.B.A., Ronquin C.C., Perón M.C.C. (2005) Balanço de carbono em duas espécies lenhosas de Cerrado cultivadas sob irradiação solar plena e sombreadas. In: Scariot A., Silva J.C.S., Felfili J.M. (Eds), Cerrado: ecologia, diversidade e conservação. Ministério do Meio Ambiente, Brasília, DF, Brazil, pp. 197-218.

Rascher U., Liebig M., Lüttge U. (2000) Evaluation of instant light-response curves of chlorophyll fluorescence parameters obtained with a portable chlorophyll fluorometer on site in the field. Plant, Cell and Environment, 23, 1397-1405.

Ratter J.A., Bridgewater S., Ribeiro F. (2006) Biodiversity patterns of the woody vegetation of the Brazilian Cerrado. In: Pennington R.T., Lewis G.P., Ratter J.A. (Eds), Neotropical savannas and seasonality: dry forest plant diversity, biogeography and 
conservation. CRC Press, Boca Raton, FL, USA, pp. 31-66.

Reich P.B., Wright I.J., Cavender-Bares J., Craine J.M., Oleksyn J., Westoby M., Walters M.B. (2003) The evolution of plant functional variation: traits, spectra, and strategies. International Journal of Plant Science, 164, S142-S164.

Ribeiro R.A., Ramos A.C.S., Lemos Filho J.P., Lovato M.B. (2005) Genetic variation in remnant populations of Dalbergia nigra (Papilionoideae), an endangered tree from the Brazilian Atlantic Forest. Annals of Botany, 95, 1171-1177.

Ribeiro R.A., Lavin M., Lemos-Filho J.P., Mendonça Filho C.V., Santos F.R., Lovato M.B. (2007) The genus Machaerium (Leguminosae) is more closely related to Aeschynomene Sect. Ochopodium than to Dalbergia: inferences from combined sequence data. Systematic Botany, 32, 762-771.

Ribeiro R.A., Lemos-Filho J.P., Ramos A.C.S., Lovato M.B. (2011) Phylogeography of the rosewood Dalbergia nigra (Fabaceae): insights into the evolutionary history and conservation of the Brazilian Atlantic Forest. Heredity, 106, 46-57.

Sánchez-Gómez D., Valladares F., Zavala M.A. (2006) Functional traits and plasticity underlying shade tolerance in seedlings of four Iberian forest tree species. Tree Physiology, 26, 1425-1433.
Silva L.C.R., Stenberg L., Haridasan M., Hoffmann W.A., Miralles-Wilhelm F., Franco A.C. (2008) Expansion of gallery forests into Central Brazilian savannas. Global Change Biology, 14, 2108-2118.

Valladares F., Guzmán B. (2006) Canopy structure and spatial heterogeneity of understory light in abandoned Holm oak woodlands. Annals of Forest Science, 63, 749-761.

Valladares F., Niinemets Ü. (2007) The architecture of plant crowns: from design rules to light capture and performance. In: Pugnaire F., Valladares F (Eds), Functional plant ecology. CRC Press, Boca Raton, FL, USA, pp. 101-150.

Valladares F., Niinemets Ü. (2008) Shade tolerance, a key plant feature of complex nature and consequences. Annual Review of Ecology, Evolution and Systematics, 38, 237-257.

Valladares F., Chico J.M., Aranda I., Balaguer L., Dizengremel P., Manrique E., Dreyer E. (2002a) Greater high light seedling tolerance of Quercus robur over Fagus sylvatica is linked to a greater physiological plasticity. Trees, 16, 395-403.

Valladares F., Skillman J.B., Pearcy R.W. (2002b) Convergence in light capture efficiencies among tropical forest understory plants with contrasting crown architectures: a case of morphological com- pensation. American Journal of Botany, 89, 12751284.

Valladares F., Hernández L.G., Dobarro I., GarcíaPérez C., Sanz R., Pugnaire F.I. (2003) The ratio of leaf to total photosynthetic area influences shade survival and plastic response to light of greenstemmed leguminous shrub seedlings. Annals of Botany, 91, 577-584.

Valladares F., Arrieta S., Aranda I., Lorenzo D., Sanchez-Gomes D., Tena D., Suárez F., Pardos A. (2005) Shade tolerance, photoinhibition sensitivity and phenotypic plasticity of Ilex aquifolium in continental Mediterranean sites. Tree Physiology, 25, 1041-1052.

Valladares F., Sanchez-Gomes D., Zavala M.A. (2006) Quantitative estimation of phenotypic plasticity: bridging the gap between the evolutionary concept and its ecological applications. Journal of Ecology, 94, 1103-1116.

Valladares F., Gianoli E., Gómez J.M. (2007) Ecological limits to plant phenotypic plasticity. Tansley review. New Phytologist, 176, 749-763. 